Check for updates

Cite this: Chem. Sci., 2019, 10, 6855

๑ All publication charges for this article have been paid for by the Royal Society of Chemistry

Received 23rd February 2019

Accepted 3rd June 2019

DOI: $10.1039 / \mathrm{c} 9 \mathrm{sc00931k}$

rsc.li/chemical-science

\section{Chemical strategies to modify amyloidogenic peptides using iridium(III) complexes: coordination and photo-induced oxidation $\uparrow$}

\author{
Juhye Kang,,$^{\mathrm{ab}}$ Jung Seung Nam, $+^{\mathrm{b}}$ Hyuck Jin Lee, ${ }^{\mathrm{ac}}$ Geewoo Nam, ${ }^{\mathrm{ab}}$ \\ Hyun-Woo Rhee, ${ }^{d}$ Tae-Hyuk Kwon*b and Mi Hee Lim (D)*a
}

\begin{abstract}
Amyloidogenic peptides are considered central pathological contributors towards neurodegeneration as observed in neurodegenerative disorders [e.g., amyloid- $\beta$ (A $\beta$ ) peptides in Alzheimer's disease $(A D)$ ]; however, their roles in the pathologies of such diseases have not been fully elucidated since they are challenging targets to be studied due to their heterogeneous nature and intrinsically disordered structure. Chemical approaches to modify amyloidogenic peptides would be valuable in advancing our molecular-level understanding of their involvement in neurodegeneration. Herein, we report effective chemical strategies for modification of $A \beta$ peptides (i.e., coordination and coordination-/photo-mediated oxidation) implemented by a single Ir(III) complex in a photodependent manner. Such peptide variations can be achieved by our rationally designed Ir(II) complexes (Ir-Me, Ir-H, Ir-F, and Ir-F2) leading to significantly modulating the aggregation pathways of two main $A \beta$ isoforms, $A \beta_{40}$ and $A \beta_{42}$, as well as the production of toxic $A \beta$ species. Overall, we demonstrate chemical tactics for modification of amyloidogenic peptides in an effective and manageable manner utilizing the coordination capacities and photophysical properties of transition metal complexes.
\end{abstract}

\section{Introduction}

A substantial amount of research effort has been dedicated towards identifying the association of amyloidogenic peptides with the pathologies of neurodegenerative diseases. Among these amyloidogenic peptides, amyloid- $\beta$ (A $\beta)$, a proteolytic product of the amyloid precursor protein found in the $\mathrm{AD}$ affected brain with a self-aggregation propensity, has been implicated as a pathological factor in Alzheimer's disease (AD).$^{1-4}$ As the main component of senile plaques, $\mathrm{A} \beta$ accumulation is a major pathological feature of $\mathrm{AD} .{ }^{1-3,5}$ Recent developments in $\mathrm{A} \beta$ research (e.g., clinical failures of $\mathrm{A} \beta$-directed therapeutics) have led to the re-evaluation of the amyloid cascade hypothesis. ${ }^{6} \mathrm{~A} \beta$ pathology, however, remains a pertinent facet of the disease with indications of $\mathrm{A} \beta$ oligomers as toxic species responsible for disrupting neuronal

${ }^{a}$ Department of Chemistry, Korea Advanced Institute of Science and Technology (KAIST), Daejeon 34141, Republic of Korea. E-mail: miheelim@kaist.ac.kr

${ }^{b}$ Department of Chemistry, Ulsan National Institute of Science and Technology (UNIST), Ulsan 44919, Republic of Korea. E-mail: kwon90@unist.ac.kr

${ }^{c}$ Department of Chemistry Education, Kongju National University, Gongju 32588, Republic of Korea

${ }^{d}$ Department of Chemistry, Seoul National University, Seoul 08826, Republic of Korea $\dagger$ Electronic supplementary information (ESI) available: Experimental section and Fig. S1-S19. See DOI: 10.1039/c9sc00931k

$\$$ These authors contributed equally to this work. homeostasis. ${ }^{1-3,7}$ Furthering our elucidation of $\mathrm{A} \beta$ pathology presents an investigative challenge arising from its heterogeneous nature and intrinsically disordered structure. ${ }^{1,2}$ To overcome this obstacle and advance our understanding of the $A \beta$ related contribution towards $\mathrm{AD}$, in this study, we illustrate chemical approaches to modify $\mathrm{A} \beta$ peptides at the molecular level using transition metal complexes.

Transition metal complexes have been reported to harness their ability to induce peptide modifications (e.g., hydrolytic cleavage and oxidation), inhibit the activities of enzymes, and image cellular components..$^{8-43}$ In particular, the ability of transition metal complexes to alter peptides stems from their properties, such as the capacity for peptide coordination. ${ }^{17-29,36,37}$ Herein, we report effective chemical strategies for modification of $A \beta$ peptides using a single $\operatorname{Ir}($ III) complex in a photo-dependent manner (Fig. 1). A $\beta$ modifications, achieved by our rationally engineered $\operatorname{Ir}(\mathrm{III})$ complexes, include two events: (i) complexation with $\mathrm{A} \beta$ in the absence of light; (ii) $\mathrm{A} \beta$ oxidation upon coordination and photoactivation, which can significantly regulate their aggregation and toxicity. Through our multidisciplinary studies, presented in this work, we demonstrate the development of new chemical tactics for modification of amyloidogenic peptides using transition metal complexes, useful for identifying their properties, such as aggregation, at the molecular level. 

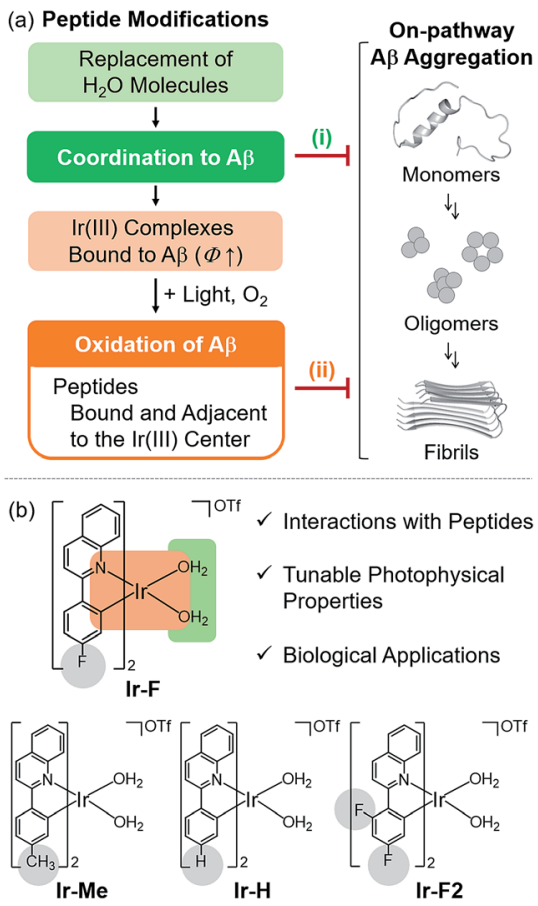

Fig. 1 Chemical approaches to modifying $A \beta$ peptides using rationally designed Ir(III) complexes. (a) Two events of modifying $A \beta$ peptides using Ir(III) complexes for controlling of $A \beta$ aggregation: (i) coordination to $A \beta$ peptides and (ii) oxidation of $A \beta$ peptides mediated by coordination and photoactivation ( $\Phi=$ emission quantum yield). (b) Design criteria and chemical structures of Ir-F, Ir-Me, Ir-H, and Ir-F2. Substituents are highlighted in gray.

\section{Results and discussion}

\section{Rational strategies for peptide modification using $\operatorname{Ir}($ III) complexes}

To chemically modify $A \beta$ peptides in a photoirradiationdependent manner (Fig. 1a), four Ir(III) complexes (Ir-Me, Ir-H, Ir-F, and Ir-F2; Fig. 1b) were rationally designed and prepared. Iridium is a third row transition metal exhibiting strong spinorbit coupling at the center of Ir(III) complexes with facile electronic transitions. ${ }^{44,45}$ This spin-orbit coupling can be further strengthened by fine-tuning the ancillary ligands of $\operatorname{Ir}(\mathrm{III})$ complexes. As a result, Ir(III) complexes confer notable photophysical properties upon excitation by relatively low energy irradiation in the visible range, including their ability to generate reactive oxygen species [ROS; e.g., singlet oxygen $\left({ }^{1} \mathrm{O}_{2}\right)$ and the superoxide anion radical $\left.\left(\mathrm{O}_{2}{ }^{-}\right)\right]$via electron or energy transfer. ${ }^{46-48}$ In addition, Ir(III) complexes with octahedral geometry are relatively stable upon light activation. ${ }^{48}$ Incorporation of 2-phenylquinoline derivatives as ligands yielded high emission quantum yield $(\Phi)$ and robust ROS generation. ${ }^{46}$ Therefore, ancillary ligands of four complexes were constructed based on the 2-phenylquinoline backbone by applying simple structural variations to provide appropriate structural and electronic environments to promote the photochemical activity of the corresponding Ir(III) complexes. ${ }^{46}$ Moreover, fluorine atoms were introduced into the ancillary ligand framework affording Ir-F and Ir-F2 to chemically impart the ability to interact with $\mathrm{A} \beta$ through hydrogen bonding, alter photophysical properties of the complexes, and enhance the molecules' biocompatibility. ${ }^{49-51}$ Two water $\left(\mathrm{H}_{2} \mathrm{O}\right)$ molecules were incorporated as ligands to enable covalent coordination to $\mathrm{A} \beta$ via replacement with amino acid residues of the peptide, e.g., histidine (His) ${ }^{20,52,53}$ The four Ir(III) complexes were synthesized following previously reported procedures with modifications (Scheme 1 and Fig. S1-S3 $\uparrow$ ). ${ }^{20,54-56}$ As depicted in Fig. S4 and S5, $\dagger$ these Ir(III) complexes were confirmed to coordinate to His or $\mathrm{A} \beta$ in both $\mathrm{H}_{2} \mathrm{O}$ and an organic solvent [i.e., dimethyl sulfoxide (DMSO)] under our experimental conditions.

\section{Coordination-dependent photophysical properties and ROS production of Ir(III) complexes}

Photophysical properties of the prepared Ir(III) complexes were investigated by UV-vis and fluorescence spectroscopy. As shown in Table 1 and Fig. S6, $\dagger$ in the absence of His or A $\beta$, low $\Phi$ values of the four Ir(III) complexes were observed, along with relatively poor ${ }^{1} \mathrm{O}_{2}$ generation with photoactivation. Note that a solar simulator (Newport IQE-200) was used to irradiate the samples at a constant intensity ( 1 sun light; $100 \mathrm{~mW} \mathrm{~cm}^{-2}$ ). Upon addition of His, the $\Phi$ values of the four Ir(III) complexes drastically increased (e.g., $\Phi_{\mathbf{I r}-\mathbf{F}}$ $=0.0071$ versus $\Phi_{\text {Ir-F+His }}=0.26$; Table 1), indicating His coordination of the complexes, which was further confirmed by electrospray ionization-mass spectrometry (ESI-MS) (Fig. S5a †). The $\Phi$ values and ${ }^{1} \mathrm{O}_{2}$ formation of the four $\operatorname{Ir}(\mathrm{III})$ complexes with His binding exhibited trends similar to their binding affinity with His (Ir-F $>$ Ir-H $>$ Ir-Me $>$ Ir-F2). Ir-F, indicating the strongest binding affinity with His (Fig. S5b†), among the four Ir(III) complexes, showed notable binding affinities towards different $\mathrm{A} \beta$ species (for monomers, $K_{\mathrm{d}}=1.6 \times 10^{-4} \mathrm{M}$; for oligomers, $K_{\mathrm{d}}=2.6 \times$ $10^{-4} \mathrm{M}$; for fibrils, $K_{\mathrm{d}}=7.1 \times 10^{-4} \mathrm{M}$; Fig. S7†). Ir-F, exhibiting a relatively high value of $\Phi$ upon His binding, also produced significant amounts of ${ }^{1} \mathrm{O}_{2}$ and $\mathrm{O}_{2}{ }^{--}$in the presence of His with

(a)

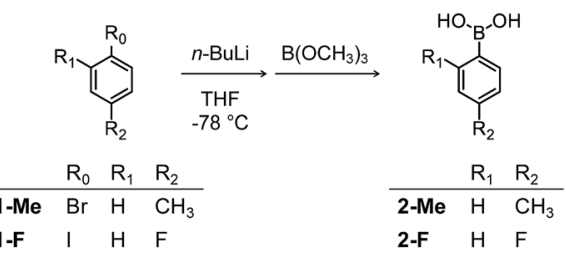

(b)

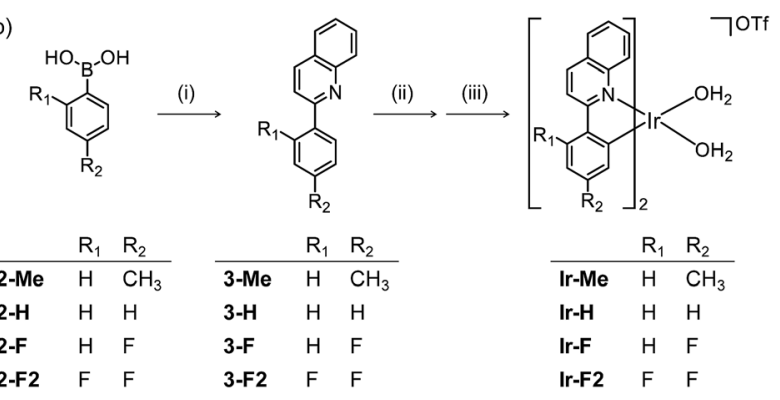

Scheme 1 Synthetic routes to $\operatorname{Ir}(I I I)$ complexes. Reagents and conditions: (i) 2-chloroquinoline, $\mathrm{Pd}\left(\mathrm{PPh}_{3}\right)_{4}, \mathrm{THF} / \mathrm{K}_{2} \mathrm{CO}_{3}$ (aq), $\Delta_{\text {; }}$ (ii) $\mathrm{IrCl}_{3} \cdot n \mathrm{H}_{2} \mathrm{O}$, 2-methoxyethanol/ $\mathrm{H}_{2} \mathrm{O}, \Delta$; (iii) AgOTf, $\mathrm{CH}_{3} \mathrm{OH} / \mathrm{CH}_{2} \mathrm{Cl}_{2}$. 
Table 1 Photophysical properties of Ir(III) complexes

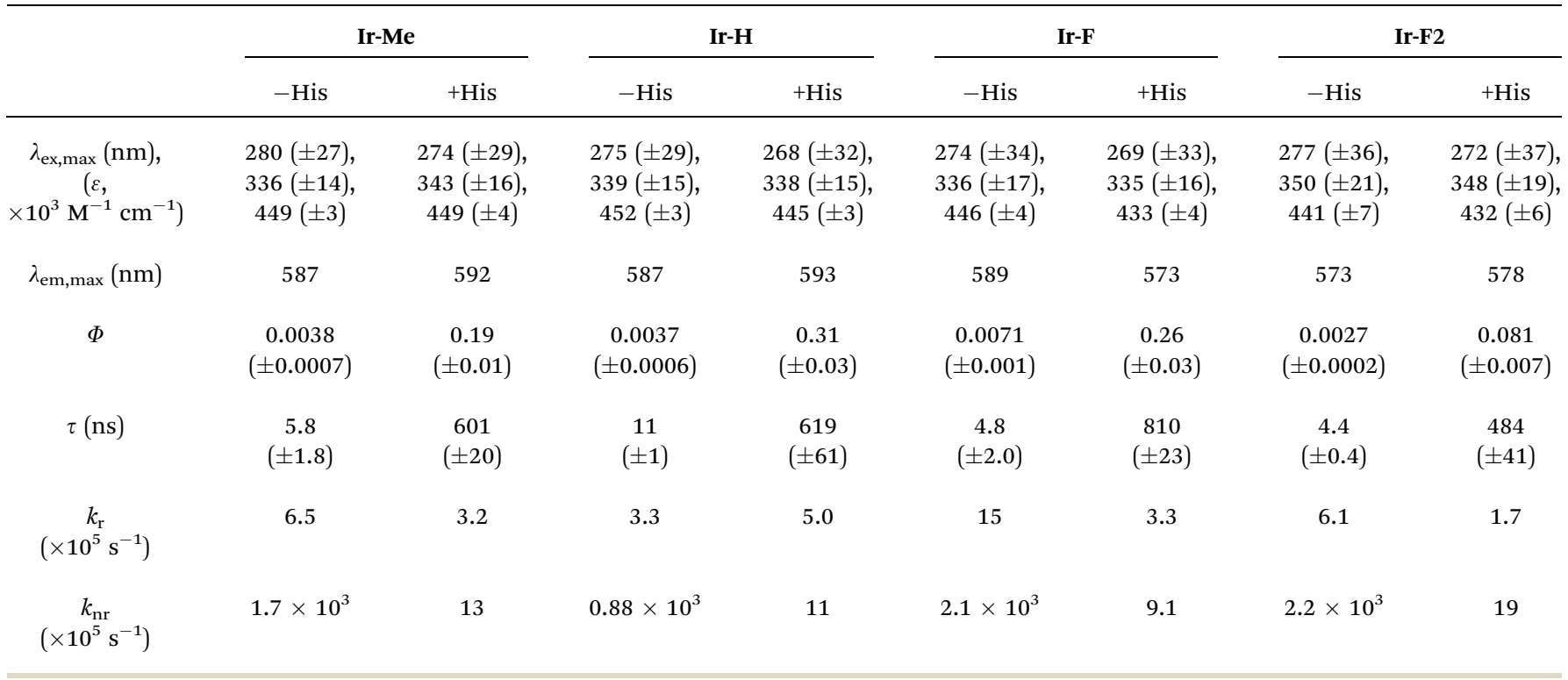

photoactivation (Fig. S6 and S8†). Based on these properties, we selected Ir-F as a representative candidate of our $\operatorname{Ir}(\mathrm{III})$ complexes and illustrated its ability to modify $\mathrm{A} \beta$ peptides in detail (vide infra).

\section{Photoirradiation-dependent peptide modification using $\operatorname{Ir}(\mathrm{III})$ complexes}

Modification of $\mathrm{A} \beta$ peptides upon treatment with Ir-F was monitored via mass spectrometric techniques [i.e., ESI-MS, ESI$\mathrm{MS}^{2}$, and ion mobility-mass spectrometry (IM-MS)]. The ESI-MS analysis of Ir-F-treated $A \beta$ samples revealed the complex formation between $\mathbf{A} \beta$ and $\mathbf{I r}-\mathbf{F}^{\prime}$ [the Ir-F form that does not have two $\mathrm{H}_{2} \mathrm{O}$ molecules bound to the $\operatorname{Ir}(\mathrm{III})$ center; Fig. 2b] in the absence of light as an indication at $1653 \mathrm{~m} / \mathrm{z}$ (Fig. 2a, middle; green). To identify the molecular species corresponding to 1653 $\mathrm{m} / \mathrm{z}$, the peak was further analyzed via ESI-MS ${ }^{2}$ in conjunction with collision-induced dissociation (CID; Fig. 2c). The detected ion fragments exhibited $\mathrm{m} / \mathrm{z}$ values attributed to $\mathrm{A} \beta_{40}$ and Ir-F'. Therefore, our MS results demonstrate the complexation between $\mathrm{A} \beta$ and Ir-F with the loss of two $\mathrm{H}_{2} \mathrm{O}$ molecules from the Ir(III) center (Ir-F' $;$ Fig. 2b). Note that the $m / z$ value of the Ir-F' (a)

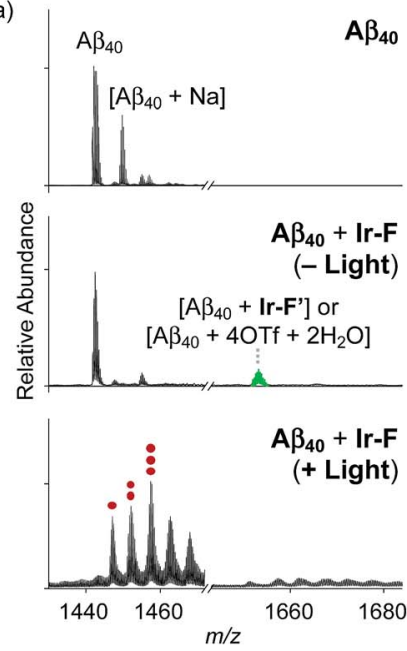

(b)

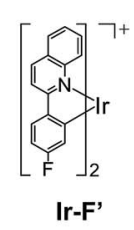

(e) (c)

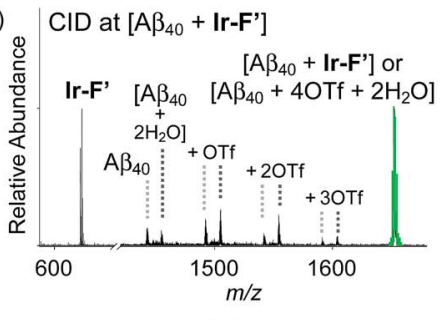

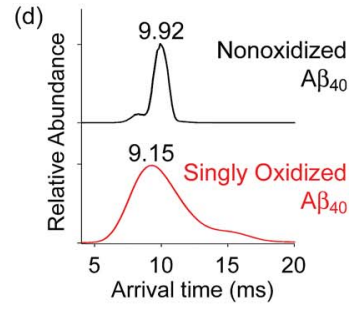

35

(e) $\quad \mathbf{A} \beta_{40}$ : DAEFRHDSGYEVHHQKLVFFAEDVGSNKGAIIGLMVGGVV

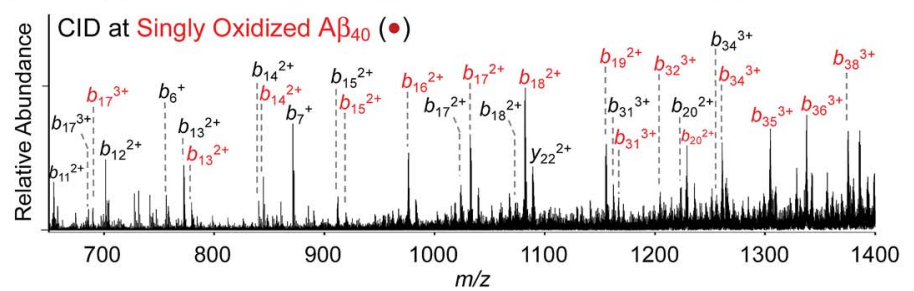

Fig. 2 Analysis of $A \beta_{40}$ species generated upon treatment with Ir-F. (a) ESI-MS spectra of Ir-F-incubated +3 -charged $A \beta_{40}$ with and without light. The peak indicated in green corresponds to a complex of $A \beta_{40}$ and Ir- $F^{\prime}$ [structure shown in (b)]. The peaks corresponding to oxidized $A \beta_{40}$ species are indicated with red dots. The number of red dots represents the number of oxygen atoms incorporated into $A \beta_{40}$. (c) Collisioninduced dissociation (CID) spectrum at $1653 \mathrm{~m} / \mathrm{z}$ [green peak from (a)]. (d) Arrival time distributions (ATDs) between nonoxidized and singly oxidized $A \beta_{40}$ monomers. (e) Sequence of $A \beta_{40}$ and CID spectrum of the singly oxidized $A \beta_{40}$ found in (a). Monooxidized $b$ fragments are denoted in red. Charges are omitted in the MS spectra. Conditions: $\left[A \beta_{40}\right]=100 \mu \mathrm{M} ;[\mathrm{Ir}-\mathrm{F}]=500 \mu \mathrm{M} ; 37^{\circ} \mathrm{C} ; 1 \mathrm{~h}$; no agitation; 1 sun light for $10 \mathrm{~min}$ (for the samples treated with light); aerobic conditions. 
$\mathrm{A} \beta_{40}$ complex is equal to that of $\left[\mathrm{A} \beta_{40}+4 \mathrm{OTf}+2 \mathrm{H}_{2} \mathrm{O}\right]$; thus, we cannot rule out the co-existence of the complex and an OTf adduct.

Upon photoirradiation, the ESI-MS analysis of Ir-F-treated $\mathrm{A} \beta_{40}$ samples led to the detection of oxidized $A \beta_{40}$ (Fig. 2a, bottom). $A \beta_{40}$ oxidation manifested a conformational change as probed by IM-MS (Fig. 2d). The most dominant arrival time indicated a peak at $9.92 \mathrm{~ms}$. These results suggest that $\mathrm{A} \beta_{40}$ oxidation induced by Ir-F can alter the structural distribution of $\mathrm{A} \beta_{40}$. Similar observations were observed with Ir-Me, Ir-H, and Ir-F2, where the complexes were able to oxidize $A \beta_{40}$ and consequently vary its structural distribution (Fig. S9 and S10 $\dagger$ ). In order to determine the location of peptide oxidation, the $A \beta$ fragment ions, generated by selectively applying collisional energy to singly oxidized A $\beta$, were analyzed by ESI-MS ${ }^{2}$ (Fig. 2e). All $b$ fragments smaller than $b_{13}$ were detected in their nonoxidized forms, while those larger than $b_{34}$ were only monitored in their oxidized forms. The $b$ fragments between $b_{13}$ and $b_{34}$ were indicated in both their oxidized and nonoxidized forms. Such observations, along with previous reports regarding $A \beta$ oxidation, ${ }^{19,57}$ suggest His13, His14, and Met35 of $\mathrm{A} \beta$ as plausible oxidation sites. Collectively, our studies demonstrate that $\mathrm{A} \beta$ peptides can be modified upon treatment with Ir-F [(i) coordination to $\mathrm{A} \beta$ by replacing two $\mathrm{H}_{2} \mathrm{O}$ molecules with the peptide in the absence of light; (ii) coordination-mediated oxidation of $\mathrm{A} \beta$ at three possible amino acid residues (e.g., His13, His14, and Met35) upon photoactivation (Fig. 1a)]. Note that the $A \beta$ samples produced by treatment of photoactivated IrF showed high fluorescence intensity and were relatively stable in both $\mathrm{H}_{2} \mathrm{O}$ and cell growth media (Fig. S11†).

\section{Effects of peptide modifications triggered by $\operatorname{Ir}($ III) complexes on $A \beta$ aggregation}

Based on the photoirradiation-dependent $A \beta$ modifications by $\operatorname{Ir}($ III) complexes, the impact of such variations on the aggregation of $A \beta$ was determined employing $A \beta_{40}$ and $A \beta_{42}$, two main $A \beta$ isoforms found in the $\mathrm{AD}$-affected brain..$^{2-4,58-62}$ For these experiments, freshly prepared $A \beta$ solutions were treated with $\operatorname{Ir}(\mathrm{III})$ complexes with and without light under both aerobic and anaerobic conditions. The molecular weight (MW) distribution and the morphology of resultant $A \beta$ species were analyzed by gel electrophoresis with Western blotting (gel/Western blot) using an anti-A $\beta$ antibody (6E10) and transmission electron microscopy (TEM), respectively (Fig. 3a).

Under aerobic conditions (Fig. 3b, left), the aggregation of $\mathrm{A} \beta_{40}$ was affected by treatment with Ir-F prompting a shift in the MW distributions in the absence of light. Photoactivation of the Ir-F-treated $A \beta_{40}$ sample resulted in a more diverse MW distribution compared to that of the corresponding sample without light (light, $\mathrm{MW} \leq 100 \mathrm{kDa}$; no light, $\mathrm{MW}<15 \mathrm{kDa}$ ). The distinct modulation of $A \beta_{40}$ aggregation upon addition of Ir-F with photoirradiation is likely a consequence of the complex's ability to generate ${ }^{1} \mathrm{O}_{2}$ and oxidize $\mathrm{A} \beta$ through photoactivation as observed in our spectrometric studies (vide supra; Fig. 2). Therefore, the same experiments were performed under anaerobic conditions to directly monitor the role of $\mathrm{O}_{2}$ in $\mathbf{I r}-\mathbf{F}^{\prime} \mathbf{S}$

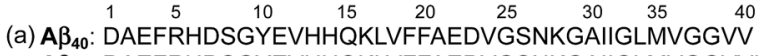
$A \beta_{42}$ : DAEFRHDSGYEVHHQKLVFFAEDVGSNKGAIIGLMVGGVVIA

$\underset{A \beta}{\text { Fresh }} \stackrel{ \pm \operatorname{Ir}(\text { III) Complexes }}{\longrightarrow} \underset{ \pm \mathrm{O}_{2}}{\stackrel{ \pm \text { Light }}{\longrightarrow} \frac{24 \mathrm{~h}}{37^{\circ} \mathrm{C} \text {, Agitation }}} \begin{gathered}\mathrm{A} \beta \\ \text { Species }\end{gathered}$

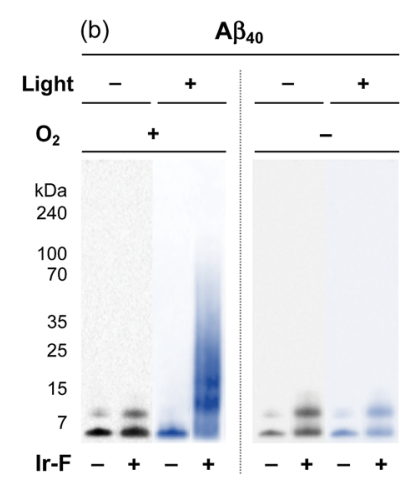

(c) $\quad A \beta_{42}$ (d)

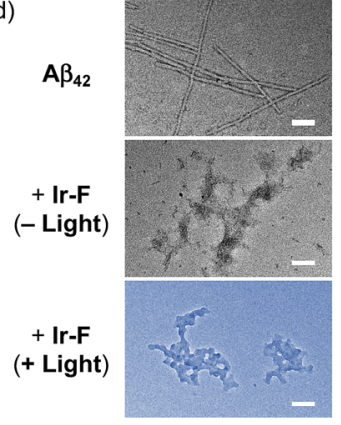

(e)

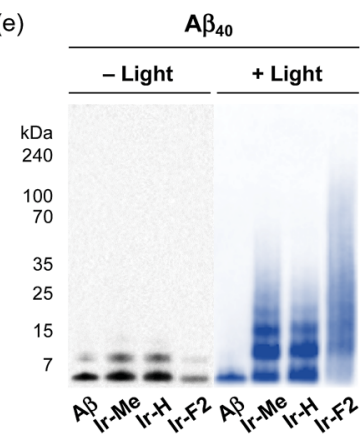

Fig. 3 Change in the formation of $A \beta$ aggregates by incubation with Ir(III) complexes. (a) Sequences of $A \beta_{40}$ and $A \beta_{42}$ and scheme of the inhibition experiments. (b, $c$, and e) Analysis of the resultant $A \beta_{40}$ and $A \beta_{42}$ species generated under various conditions by gel/Western blot with an anti-A $\beta$ antibody (6E10). (d) TEM images of the resultant $A \beta_{42}$ aggregates (scale bar $=100 \mathrm{~nm}$ ). Conditions: $[A \beta]=25 \mu \mathrm{M}$; $[\operatorname{lr}($ III) complexes] $=250 \mu \mathrm{M} ; 37^{\circ} \mathrm{C} ; 24 \mathrm{~h}$; constant agitation; 1 sun light for $10 \mathrm{~min}$ (for the samples treated with light).

modulative reactivity against $A \beta_{40}$ aggregation. In the absence of $\mathrm{O}_{2}$ (Fig. 3b, right), $\mathrm{A} \beta_{40}$ aggregation was also altered by Ir-F regardless of light treatment. Our results suggest that both light and $\mathrm{O}_{2}$ are important in the regulation of $\mathrm{A} \beta_{40}$ aggregation through coordination-/photo-mediated peptide oxidation triggered by Ir-F. In addition, in the absence of light and $\mathrm{O}_{2}, \mathrm{~A} \beta_{40}$ aggregation is directed by the covalent interactions between Ir-F and the peptide. Similar modulation of $A \beta_{42}$ aggregation was observed upon incubation with Ir-F exhibiting different MW distributions compared to the $A \beta_{42}$ samples without Ir-F in the absence and presence of light and $\mathrm{O}_{2}$ (Fig. 3c). Moreover, smaller amorphous aggregates of both $A \beta_{40}$ and $A \beta_{42}$, reported to be less toxic, ${ }^{\mathbf{6 3 , 6 4}}$ were visualized by TEM from the samples containing Ir-F regardless of irradiation (Fig. 3d and S12c $\dagger$ ).

Furthermore, preformed $\mathrm{A} \beta$ aggregates, generated at various preincubation time points (i.e., 2, 4, and $24 \mathrm{~h}$ ), were disassembled and their aggregation pathways were altered when IrF was introduced (Fig. S13 $\dagger$ ). Such Ir-F-induced effects on preformed $A \beta$ aggregates were observed to be dependent on photoirradiation. Moreover, the aggregation of both $\mathrm{A} \beta_{40}$ and $\mathrm{A} \beta_{42}$ 
was also changed with addition of the other Ir(III) complexes (i.e., Ir-Me, Ir-H, and Ir-F2) with and without light (Fig. 3e, S12 and $\mathbf{S} 13 \dagger)$. In addition to $\mathrm{A} \beta$, Ir-F was able to interact with and modify other amyloidogenic peptides [i.e., $\alpha$-synuclein $(\alpha$-Syn) and human islet amyloid polypeptide (hIAPP)] affecting their aggregation pathways (Fig. S14†).

\section{Cytotoxicity of $A \beta$ species generated upon incubation with Ir(III) complexes}

Prior to cytotoxicity measurements, the resultant species upon $24 \mathrm{~h}$ treatment of $\mathrm{A} \beta_{40}$ with Ir-F with light exposure were incubated with murine Neuro-2a (N2a) neuroblastoma cells in order to determine their cellular uptake. As depicted in Fig. S15, $\dagger$ the lysates of the cells added with the resultant species for $24 \mathrm{~h}$, analyzed by inductively coupled plasma-mass spectrometry (ICP-

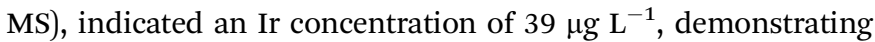
the cellular uptake of the species containing $\operatorname{Ir}($ III). Note that the Ir concentration $\left(0.17\right.$ and $\left.34 \mu \mathrm{g} \mathrm{L}^{-1}\right)$ was measured from the lysates of the cells treated only with either $A \beta_{40}$ or Ir-F, respectively. Moving forward, the toxicity of $\mathrm{A} \beta$ species produced by treatment with our Ir(III) complexes was monitored by the MTT assay [MTT $=3$-(4,5-dimethyl-2-thiazolyl)-2,5-diphenyl-2 $H$-tetrazolium bromide] (Fig. 4). The cytotoxicity of $A \beta_{40}$ species incubated with our Ir(III) complexes was noticeably reduced in a photoirradiation-dependent manner. In the absence of light, the $\mathrm{A} \beta_{40}$ samples incubated with our Ir(III) complexes exhibited a decrease in cytotoxicity ( $c a .20 \%$ ) compared to the sample of the complex-free $A \beta_{40}$. As for the photoirradiated samples, $A \beta_{40^{-}}$ induced toxicity was lowered by $c a$. $35 \%$ by treatment with our Ir(III) complexes. This result suggests that modification of $\mathrm{A} \beta$,
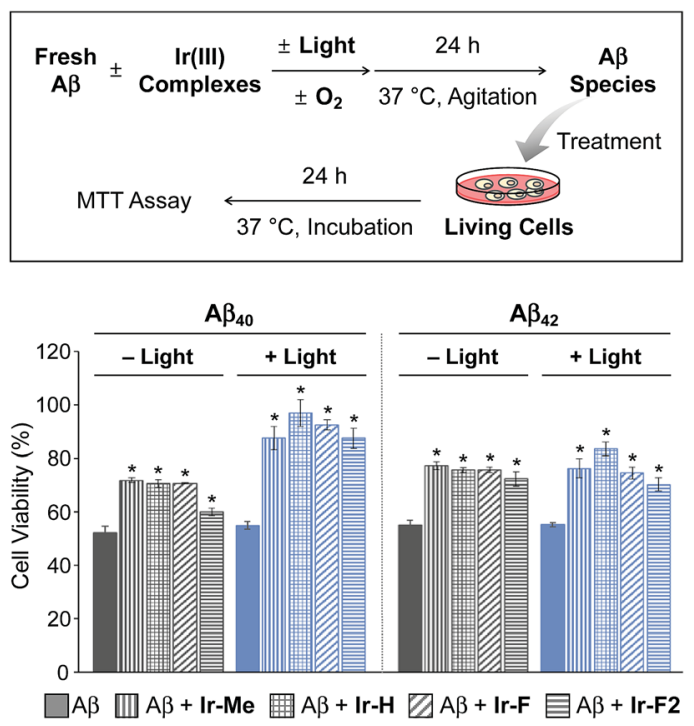

Fig. 4 Viability of N2a cells upon $24 \mathrm{~h}$ treatment with $A \beta$ species produced by incubation with Ir(III) complexes for $24 \mathrm{~h}$ with and without light activation. Cell viability (\%), measured by the MTT assay, was calculated and compared with that of samples treated with an equivalent amount of DMSO only. Conditions (final concentration): $[A \beta]=20 \mu \mathrm{M} ;[\operatorname{lr}($ III) complexes $]=5 \mu \mathrm{M}$. Error bars represent the standard error of the mean from three independent experiments. $* P<$ 0.05 .

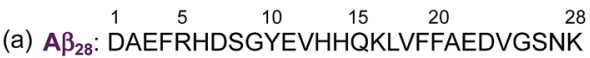
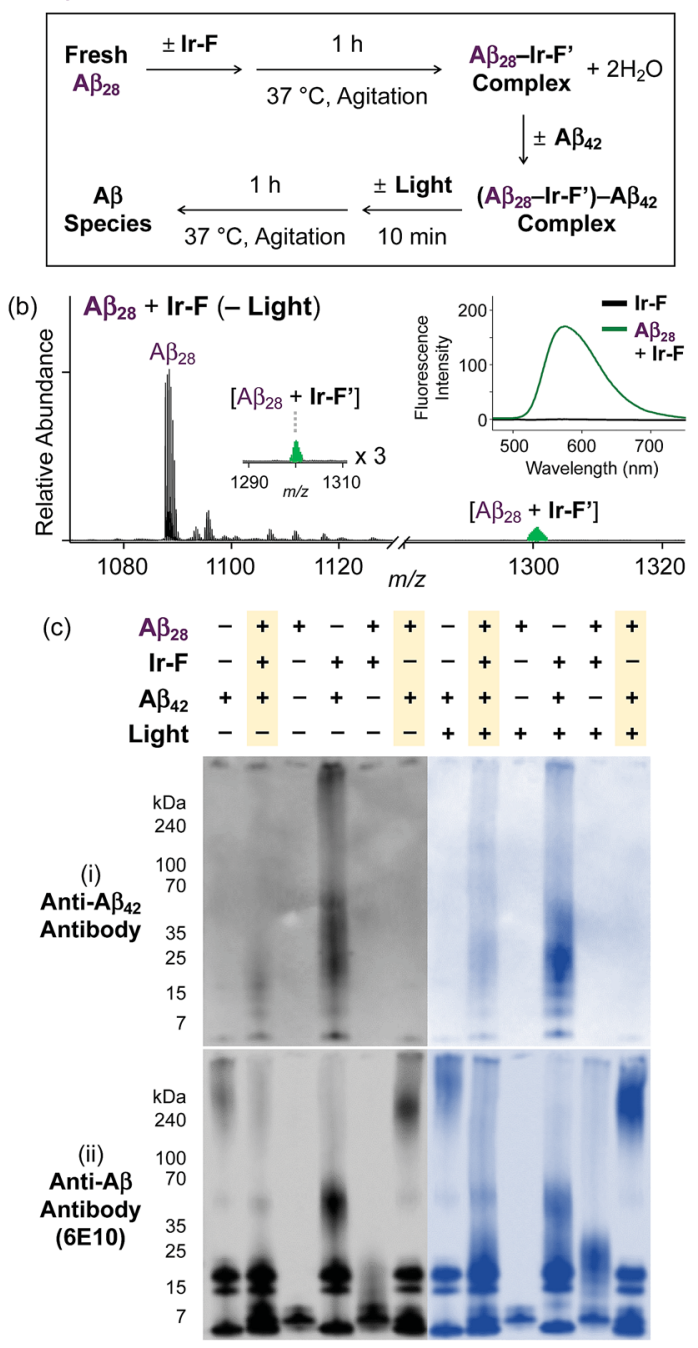

(d)

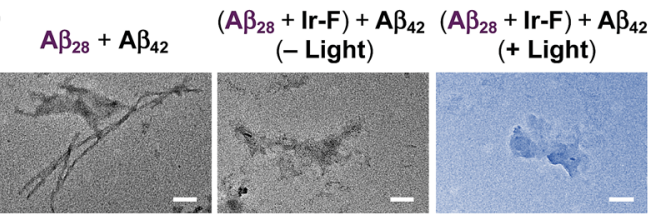

Fig. 5 Impact of Ir-F-preincubated $A \beta_{28}$ on the aggregation of $A \beta_{42}$. (a) Sequence of $A \beta_{28}$ and scheme of the experiments. (b) ESI-MS spectrum of +3 -charged $A \beta_{28}$ upon incubation with Ir-F. The complex peak is indicated in green. (Inset) Fluorescence response of Ir-F to $A \beta_{28}\left(\lambda_{\text {ex }}=433 \mathrm{~nm}\right)$. Charges are omitted in the MS spectra. Conditions: $\left[A \beta_{28}\right]=100 \mu \mathrm{M}$; [Ir-F] $=100 \mu \mathrm{M} ; 37^{\circ} \mathrm{C} ; 1 \mathrm{~h}$; no agitation; 1 sun light for $10 \mathrm{~min}$ (for the samples treated with light); aerobic conditions. (c) Analysis of the resultant $A \beta$ species, obtained by addition of $A \beta_{42}$ into Ir-F preincubated with $A \beta_{28}$, by gel/Western blot with (i) anti-A $\beta_{42}$ and (ii) anti-A $\beta$ (6E10) antibodies. (d) TEM images of the resultant $A \beta$ aggregates (scale bar $=100 \mathrm{~nm}$ ). Conditions: $\left[A \beta_{28}\right]=$ $50 \mu \mathrm{M} ;[\mathrm{lr}-\mathrm{F}]=10 \mu \mathrm{M} ;\left[\mathrm{A} \beta_{42}\right]=20 \mu \mathrm{M} ; 37^{\circ} \mathrm{C} ; 2 \mathrm{~h}$; constant agitation; 1 sun light for $10 \mathrm{~min}$ (for the samples treated with light); aerobic conditions. 
such as oxidation, could attenuate $A \beta$-triggered toxicity in living cells. ${ }^{65}$ Furthermore, the cytotoxicity of $A \beta_{42}$ species formed with Ir(III) complexes was also diminished by $c a .20 \%$ regardless of photoactivation. Note that the survival ( $\geq 80 \%$ ) of cells treated with our $\operatorname{Ir}(\mathrm{III})$ complexes at the concentration used for cell studies with $A \beta$ peptides was observed with and without light exposure (Fig. S16†).

\section{Ternary complexation with $\mathbf{A} \beta$ and intramolecular and intermolecular $\mathbf{A} \boldsymbol{\beta}$ oxidation}

Premised on Ir-F's covalent bond formation with $\mathrm{A} \beta$ and oxidation of $\mathrm{A} \beta$ (vide supra), additional studies regarding ternary complexation and promotion of intermolecular oxidation of $\mathrm{A} \beta$ were carried out employing Ir-F (Fig. 5). $\mathrm{A} \beta_{28}$, a fragment of $A \beta$ equipped with the metal binding and selfrecognition sites of the peptide with a relatively low propensity to aggregate than the full-length peptides, $A \beta_{40}$ and $\mathrm{A} \beta_{42},{ }^{\mathbf{1 , 6 6 - 6 8}}$ was used to form a complex with $\operatorname{Ir}^{-F^{\prime}}$ (Fig. 2b) as evidenced by ESI-MS (1301 $\mathrm{m} / \mathrm{z}$; Fig. $5 \mathrm{~b})$ and increased fluorescence (Fig. 5b, inset). As shown in Fig. 5a, following incubation, the sample of the $A \beta_{28}-\mathbf{I r}-\mathbf{F}^{\prime}$ complex was treated with freshly prepared $A \beta_{42}$ to monitor its effect on $A \beta_{42}$ aggregation. Based on the gel/Western blot and TEM analyses, the aggregation of $\mathrm{A} \beta_{42}$ was modulated by the $\mathrm{A} \beta_{28}-\mathbf{I r}-\mathbf{F}^{\prime}$ complex (Fig. $5 \mathrm{c}$ and $\mathrm{d}$ ). Such modulative reactivity of the $\mathrm{A} \beta_{28}-\mathbf{I r}-\mathbf{F}^{\prime}$ complex was also observed against $A \beta_{40}$ aggregation (Fig. S17†). Our mass spectrometric studies confirmed that such control of $A \beta_{42}$ aggregation by the $\mathrm{A} \beta_{28}-\mathbf{I r}-\mathbf{F}^{\prime}$ complex was a result of ternary complex formation with $\mathrm{A} \beta_{42}$, i.e., $\left(\mathrm{A} \beta_{28}-\mathbf{I r}-\mathbf{F}^{\prime}\right)-\mathrm{A} \beta_{42}$, and (ii) oxidation of $\mathrm{A} \beta$, both intramolecular and intermolecular, upon photoactivation (Fig. 6). Based on previous reports detailing intermolecular interactions between $\mathrm{A} \beta$ peptides, hydrophobic

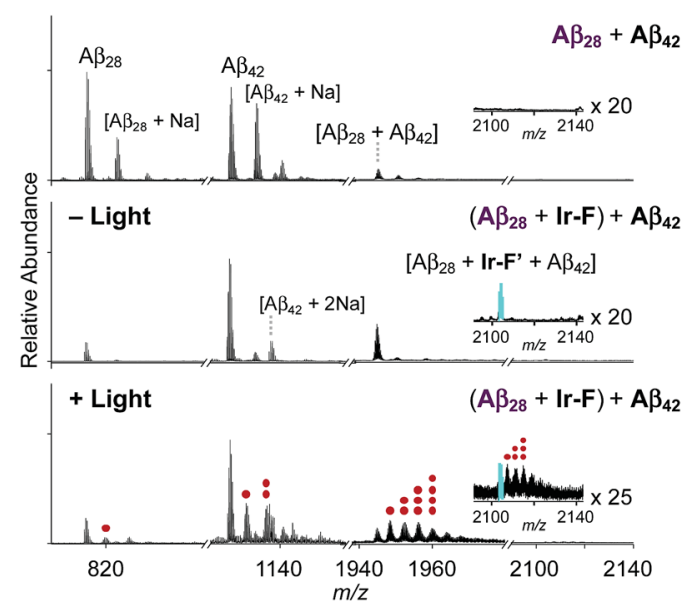

Fig. 6 ESI-MS spectra of Ir-F-incubated +4-charged $A \beta_{28}$ and $A \beta_{42}$ with and without light. The peak indicated in cyan refers to a ternary complex of $A \beta_{28}$, Ir $-F^{\prime}$, and $A \beta_{42}$. The peaks corresponding to oxidized peptides (i.e., $A \beta_{28}, A \beta_{42}$, and $A \beta_{28}$ with $A \beta_{42}$ ) are indicated with red dots. The number of red dots represents the number of oxygen atoms incorporated into each peptide. Charges are omitted in the MS spectra. Conditions: $\left[A \beta_{28}\right]=100 \mu \mathrm{M}$; $[\mathrm{Ir}-\mathrm{F}]=100 \mu \mathrm{M}$; $\left[\mathrm{A} \beta_{42}\right]=100 \mu \mathrm{M} ; 37^{\circ} \mathrm{C}$; $2 \mathrm{~h}$; no agitation; 1 sun light for $10 \mathrm{~min}$ (for the samples treated with light); aerobic conditions. interactions between the self-recognition sites (LVFFA; Fig. 3a and $5 \mathrm{a}$ ) of $\mathrm{A} \beta$ are likely responsible for ternary complexation, ${ }^{1,2,69}$ consequentially altering the aggregation pathways of $\mathrm{A} \beta$ in the absence of photoirradiation. Furthermore, these studies indicate that intermolecular oxidation of $A \beta$ can be promoted by Ir-F upon photoactivation (Fig. 6, S18, and S19†). This observation may explain the distinct difference between the modulation of $A \beta$ aggregation with and without light as the intermolecular oxidation of $A \beta$ by Ir(III) complexes could modify $\mathrm{A} \beta$ at sub-stoichiometric levels.

\section{Conclusions}

Effective chemical strategies (i.e., coordination to $\mathrm{A} \beta$ and coordination-/photo-mediated oxidation of $A \beta$ ) for modification of $\mathrm{A} \beta$ peptides using a single Ir(III) complex were rationally developed. Such dual mechanisms (i.e., coordination and oxidation) exhibiting photo-dependency for altering $\mathrm{A} \beta$ peptides are novel and effective in controlling peptide aggregation and cytotoxicity. Our Ir(III) complexes can covalently bind to $\mathrm{A} \beta$ by replacing two $\mathrm{H}_{2} \mathrm{O}$ molecules bound to the $\operatorname{Ir}(\mathrm{III})$ center with $\mathrm{A} \beta$ regardless of light and $\mathrm{O}_{2}$ [coordination to $A \beta$; Fig. 1a(i)]. In the presence of light and $\mathrm{O}_{2}, \operatorname{Ir}(\mathrm{III})$ complexes bound to $A \beta$ are capable of inducing the intramolecular and intermolecular oxidation of $\mathrm{A} \beta$ at His13, His14, and/or Met35 [oxidation of A $\beta$; Fig. 1a(ii)]. Taken together, our multidisciplinary studies demonstrate the feasibility of establishing new chemical approaches towards modification of amyloidogenic peptides (e.g., $\mathrm{A} \beta$ ) using transition metal complexes designed based on their coordination and photophysical properties. In general, chemical modifications in peptides of interest can assist in furthering our understanding of principles of their properties, such as peptide assembly. Furthermore, peptide aggregation and cytotoxicity can be affected by biomolecules, including lipid membranes $;^{\mathbf{7 0}-73}$ thus, the regulatory reactivity of $\operatorname{Ir}(\mathrm{III})$ complexes towards amyloidogenic peptides in the presence of lipid membranes will be investigated in the future.

\section{Conflicts of interest}

There are no conflicts to declare.

\section{Acknowledgements}

This work was supported by a National Research Foundation of Korea (NRF) grant funded by the Korean government [NRF2017R1A2B3002585 and NRF-2016R1A5A1009405 (to M. H. L.); NRF-2016R1A2B4009239 (to. T.-H. K.)]. J. K. acknowledges the Global Ph.D. Fellowship Program through the NRF funded by the Ministry of Education (NRF-2015HIA2A1030823). J. S. N. is grateful for the support from the ASAN Foundation Biomedical Science Scholarship. We thank Dr Shin Jung C. Lee, Yonghwan Ji, Eunju Nam, Mingeun Kim, and Jong-Min Suh for the help with MS and TEM measurements of A $\beta, \alpha$-Syn, and hIAPP. 


\section{Notes and references}

1 M. G. Savelieff, G. Nam, J. Kang, H. J. Lee, M. Lee and M. H. Lim, Chem. Rev., 2019, 119, 1221-1322.

2 I. W. Hamley, Chem. Rev., 2012, 112, 5147-5192.

3 K. P. Kepp, Coord. Chem. Rev., 2017, 351, 127-159.

4 R. Jakob-Roetne and H. Jacobsen, Angew. Chem., Int. Ed., 2009, 48, 3030-3059.

5 J. A. Hardy and G. A. Higgins, Science, 1992, 256, 184-185.

6 G. P. Morris, I. A. Clark and B. Vissel, Acta Neuropathol., 2018, 136, 663-689.

7 S. J. C. Lee, E. Nam, H. J. Lee, M. G. Savelieff and M. H. Lim, Chem. Soc. Rev., 2017, 46, 310-323.

8 A. Zamora, G. Vigueras, V. Rodríguez, M. D. Santana and J. Ruiz, Coord. Chem. Rev., 2018, 360, 34-76.

9 K. L. Haas and K. J. Franz, Chem. Rev., 2009, 109, 4921-4960.

10 R. Wai-Yin Sun, D.-L. Ma, E. L.-M. Wong and C.-M. Che, Dalton Trans., 2007, 4884-4892.

11 C.-H. Leung, H.-J. Zhong, D. S.-H. Chan and D.-L. Ma, Coord. Chem. Rev., 2013, 257, 1764-1776.

12 C.-H. Leung, S. Lin, H.-J. Zhong and D.-L. Ma, Chem. Sci., 2015, 6, 871-884.

13 D. A. Fancy and T. Kodadek, Proc. Natl. Acad. Sci. U. S. A., 1999, 96, 6020-6024.

14 V. B. Kenche, L. W. Hung, K. Perez, I. Volitakes, G. Ciccotosto, J. Kwok, N. Critch, N. Sherratt, M. Cortes, V. Lal, C. L. Masters, K. Murakami, R. Cappai, P. A. Adlard and K. J. Barnham, Angew. Chem., Int. Ed., 2013, 52, 33743378.

15 W. Zhen, H. Han, M. Anguiano, C. A. Lemere, C.-G. Cho and P. T. Lansbury, J. Med. Chem., 1999, 42, 2805-2815.

16 G. S. Yellol, J. G. Yellol, V. B. Kenche, X. M. Liu, K. J. Barnham, A. Donaire, C. Janiak and J. Ruiz, Inorg. Chem., 2015, 54, 470-475.

17 G. Son, B. I. Lee, Y. J. Chung and C. B. Park, Acta Biomater., 2018, 67, 147-155.

18 L. He, X. Wang, D. Zhu, C. Zhao and W. Du, Metallomics, 2015, 7, 1562-1572.

19 J. Kang, S. J. C. Lee, J. S. Nam, H. J. Lee, M.-G. Kang, K. J. Korshavn, H.-T. Kim, J. Cho, A. Ramamoorthy, H.-W. Rhee, T.-H. Kwon and M. H. Lim, Chem.-Eur. J., 2017, 23, 1645-1653.

20 B. Y.-W. Man, H.-M. Chan, C.-H. Leung, D. S.-H. Chan, L.-P. Bai, Z.-H. Jiang, H.-W. Li and D.-L. Ma, Chem. Sci., 2011, 2, 917-921.

21 D. J. Hayne, S. Lim and P. S. Donnelly, Chem. Soc. Rev., 2014, 43, 6701-6715.

22 H. Liu, Y. Qu and X. Wang, Future Med. Chem., 2018, 10, 679701.

23 K. J. Barnham, V. B. Kenche, G. D. Ciccotosto, D. P. Smith, D. J. Tew, X. Liu, K. Perez, G. A. Cranston, T. J. Johanssen, I. Volitakis, A. I. Bush, C. L. Masters, A. R. White, J. P. Smith, R. A. Cherny and R. Cappai, Proc. Natl. Acad. Sci. U. S. A., 2008, 105, 6813-6818.
24 B. I. Lee, S. Lee, Y. S. Suh, J. S. Lee, A.-k. Kim, O.-Y. Kwon, K. Yu and C. B. Park, Angew. Chem., Int. Ed., 2015, 54, 11472-11476.

25 A. Aliyan, T. J. Paul, B. Jiang, C. Pennington, G. Sharma, R. Prabhakar and A. A. Martí, Chem, 2017, 3, 898-912.

26 L. Messori, M. Camarri, T. Ferraro, C. Gabbiani and D. Franceschini, ACS Med. Chem. Lett., 2013, 4, 329-332.

27 X. Wang, X. Wang, C. Zhang, Y. Jiao and Z. Guo, Chem. Sci., 2012, 3, 1304-1312.

28 A. Kumar, L. Moody, J. F. Olaivar, N. A. Lewis, R. L. Khade, A. A. Holder, Y. Zhang and V. Rangachari, ACS Chem. Neurosci., 2010, 1, 691-701.

29 J.-M. Suh, G. Kim, J. Kang and M. H. Lim, Inorg. Chem., 2019, 58, 8-17.

30 C.-Y. Wong, L.-H. Chung, L. Lu, M. Wang, B. He, L.-J. Liu, C.-H. Leung and D.-L. Ma, Curr. Alzheimer Res., 2015, 12, 439-444.

31 L. Lu, H.-J. Zhong, M. Wang, S.-L. Ho, H.-W. Li, C.-H. Leung and D.-L. Ma, Sci. Rep., 2015, 5, 14619.

32 J. Suh, S. H. Yoo, M. G. Kim, K. Jeong, J. Y. Ahn, M.-s. Kim, P. S. Chae, T. Y. Lee, J. Lee, J. Lee, Y. A. Jang and E. H. Ko, Angew. Chem., Int. Ed., 2007, 46, 7064-7067.

33 J. S. Derrick, J. Lee, S. J. C. Lee, Y. Kim, E. Nam, H. Tak, J. Kang, M. Lee, S. H. Kim, K. Park, J. Cho and M. H. Lim, J. Am. Chem. Soc., 2017, 139, 2234-2244.

34 W.-h. Wu, P. Lei, Q. Liu, J. Hu, A. P. Gunn, M.-s. Chen, Y.-f. Rui, X.-y. Su, Z.-p. Xie, Y.-F. Zhao, A. I. Bush and Y.-m. Li, J. Biol. Chem., 2008, 283, 31657-31664.

35 P. S. Donnelly, A. Caragounis, T. Du, K. M. Laughton, I. Volitakis, R. A. Cherny, R. A. Sharples, A. F. Hill, Q.-X. Li, C. L. Masters, K. J. Barnham and A. R. White, J. Biol. Chem., 2008, 283, 4568-4577.

36 I. Sasaki, C. Bijani, S. Ladeira, V. Bourdon, P. Faller and C. Hureau, Dalton Trans., 2012, 41, 6404-6407.

37 D. Valensin, P. Anzini, E. Gaggelli, N. Gaggelli, G. Tamasi, R. Cini, C. Gabbiani, E. Michelucci, L. Messori, H. Kozlowski and G. Valensin, Inorg. Chem., 2010, 49, 4720-4722.

38 L.-J. Liu, W. Wang, S.-Y. Huang, Y. Hong, G. Li, S. Lin, J. Tian, Z. Cai, H.-M. D. Wang, D.-L. Ma and C.-H. Leung, Chem. Sci., 2017, 8, 4756-4763.

39 K. Vellaisamy, G. Li, C.-N. Ko, H.-J. Zhong, S. Fatima, H.-Y. Kwan, C.-Y. Wong, W.-J. Kwong, W. Tan, C.-H. Leung and D.-L. Ma, Chem. Sci., 2018, 9, 1119-1125.

40 V. Novohradsky, A. Zamora, A. Gandioso, V. Brabec, J. Ruiz and V. Marchán, Chem. Commun., 2017, 53, 5523-5526.

41 F.-X. Wang, M.-H. Chen, Y.-N. Lin, H. Zhang, C.-P. Tan, L.-N. Ji and Z.-W. Mao, ACS Appl. Mater. Interfaces, 2017, 9, 42471-42481.

42 V. Novohradsky, A. Rovira, C. Hally, A. Galindo, G. Vigueras, A. Gandioso, M. Svitelova, R. Bresolí-Obach, H. Kostrhunova, L. Markova, J. Kasparkova, S. Nonell, J. Ruiz, V. Brabec and V. Marchán, Angew. Chem., Int. Ed., 2019, 58, 6311-6315.

43 D. Yu, Y. Guan, F. Bai, Z. Du, N. Gao, J. Ren and X. Qu, Chem.-Eur. J., 2019, 25, 3489-3495.

44 Y. You, Curr. Opin. Chem. Biol., 2013, 17, 699-707. 
45 M. S. Lowry and S. Bernhard, Chem.-Eur. J., 2006, 12, 79707977.

46 J. S. Nam, M.-G. Kang, J. Kang, S.-Y. Park, S. J. C. Lee, H.-T. Kim, J. K. Seo, O.-H. Kwon, M. H. Lim, H.-W. Rhee and T.-H. Kwon, J. Am. Chem. Soc., 2016, 138, 10968-10977.

47 R. Gao, D. G. Ho, B. Hernandez, M. Selke, D. Murphy, P. I. Djurovich and M. E. Thompson, J. Am. Chem. Soc., 2002, 124, 14828-14829.

48 Z. Liu and P. J. Sadler, Acc. Chem. Res., 2014, 47, 1174-1185.

49 A. Wragg, M. R. Gill, D. Turton, H. Adams, T. M. Roseveare, C. Smythe, X. Su and J. A. Thomas, Chem.-Eur. J., 2014, 20, 14004-14011.

50 J. Zhao, Y. Yu, X. Yang, X. Yan, H. Zhang, X. Xu, G. Zhou, Z. Wu, Y. Ren and W.-Y. Wong, ACS Appl. Mater. Interfaces, 2015, 7, 24703-24714.

51 F. S. Etheridge, R. J. Fernando, S. Pejić, M. Zeller and G. Sauvé, Beilstein J. Org. Chem., 2016, 12, 1925-1938.

52 D.-L. Ma, W.-L. Wong, W.-H. Chung, F.-Y. Chan, P.-K. So, T.-S. Lai, Z.-Y. Zhou, Y.-C. Leung and K.-Y. Wong, Angew. Chem., Int. Ed., 2008, 47, 3735-3739.

53 D.-L. Ma, H.-J. Zhong, W.-C. Fu, D. S.-H. Chan, H.-Y. Kwan, W.-F. Fong, L.-H. Chung, C.-Y. Wong and C.-H. Leung, PLoS One, 2013, 8, e55751.

54 N. Nonoyama, Bull. Chem. Soc. Jpn., 1974, 47, 767-768.

55 B. Schmid, F. O. Garces and R. J. Watts, Inorg. Chem., 1994, 33, 9-14.

56 N. D. McDaniel, F. J. Coughlin, L. L. Tinker and S. Bernhard, J. Am. Chem. Soc., 2008, 130, 210-217.

57 J. Han, H. J. Lee, K. Y. Kim, S. J. C. Lee, J.-M. Suh, J. Cho, J. Chae and M. H. Lim, ACS Chem. Neurosci., 2018, 9, 800808.

58 G. Bitan, B. Tarus, S. S. Vollers, H. A. Lashuel, M. M. Condron, J. E. Straub and D. B. Teplow, J. Am. Chem. Soc., 2003, 125, 15359-15365.

59 L. Hou, I. Kang, R. E. Marchant and M. G. Zagorski, J. Biol. Chem., 2002, 277, 40173-40176.
60 S.-M. Liao, Q.-S. Du, J.-Z. Meng, Z.-W. Pang and R.-B. Huang, Chem. Cent. J., 2013, 7, 44.

61 K. Brännström, T. Islam, L. Sandblad and A. Olofsson, FEBS Lett., 2017, 591, 1167-1175.

62 V. Kadlcik, C. Sicard-Roselli, C. Houée-Levin, M. Kodicek, C. Ferreri and C. Chatgilialoglu, Angew. Chem., Int. Ed., 2006, 45, 2595-2598.

63 J. Bieschke, J. Russ, R. P. Friedrich, D. E. Ehrnhoefer, H. Wobst, K. Neugebauer and E. E. Wanker, Proc. Natl. Acad. Sci. U. S. A., 2010, 107, 7710-7715.

64 S.-J. Hyung, A. S. DeToma, J. R. Brender, S. Lee, S. Vivekanandan, A. Kochi, J.-S. Choi, A. Ramamoorthy, B. T. Ruotolo and M. H. Lim, Proc. Natl. Acad. Sci. U. S. A., 2013, 110, 3743-3748.

65 A. Taniguchi, Y. Shimizu, K. Oisaki, Y. Sohma and M. Kanai, Nat. Chem., 2016, 8, 974-982.

66 C. Cheignon, M. Tomas, D. Bonnefont-Rousselot, P. Faller, C. Hureau and F. Collin, Redox Biol., 2018, 14, 450-464.

67 M. A. Telpoukhovskaia and C. Orvig, Chem. Soc. Rev., 2013, 42, 1836-1846.

68 B. Klajnert, T. Wasiak, M. Ionov, M. Fernandez-Villamarin, A. Sousa-Herves, J. Correa, R. Riguera and E. FernandezMegia, Nanomedicine, 2012, 8, 1372-1378.

69 M. G. Savelieff, S. Lee, Y. Liu and M. H. Lim, ACS Chem. Biol., 2013, 8, 856-865.

70 S. A. Kotler, P. Walsh, J. R. Brender and A. Ramamoorthy, Chem. Soc. Rev., 2014, 43, 6692-6700.

71 M. F. M. Sciacca, S. A. Kotler, J. R. Brender, J. Chen, D.-k. Lee and A. Ramamoorthy, Biophys. J., 2012, 103, 702-710.

72 K. J. Korshavn, A. Bhunia, M. H. Lim and A. Ramamoorthy, Chem. Commun., 2016, 52, 882-885.

73 K. J. Korshavn, C. Satriano, Y. Lin, R. Zhang, M. Dulchavsky, A. Bhunia, M. I. Ivanova, Y.-H. Lee, C. La Rosa, M. H. Lim and A. Ramamoorthy, J. Biol. Chem., 2017, 292, 4638-4650. 